\title{
UMA ANÁLISE DOS SIGNIFICADOS IDEACIONAIS EM REPORTAGEM DA REVISTA NOVA ESCOLA: A REPRESENTAÇÃO DE ENSINO E DO PROFESSOR DE LÍNGUA PORTUGUESA
}

\author{
${ }^{1}$ Victor Gomes Milani, Odair Benedito Francisco \\ 'Universidade Federal De Santa Maria - UFSM, Mestrado, Palmeira das Missões - RS, ${ }^{2}$ Universidade do Oeste Paulista - \\ UNOESTE, Mestrado, Presidente Prudente, SP. E_mail: lordemilani@yahoo.com.br, odair272@yahoo.com.br.
}

\section{RESUMO}

Apesar de diretrizes nacionais como PCNs (Parâmetros Curriculares Nacionais) de 1998 e os OCNs (Orientações Curriculares Nacionais) de 2006 discorrerem sobre o ensino de língua portuguesa no Brasil, maneiras de como melhorar as propostas pedagógicas ainda são muito discutidas na esfera midiática. O objetivo desse estudo foi analisar uma reportagem de Maria Rehder publicada na revista Nova Escola em janeiro de 2010 intitulada O que ensinar em Língua Portuguesa do 60 ao 9o ano a fim de se buscar a representação de ensino e do professor de língua portuguesa nela retratada. A análise realizada foi guiada pelos princípios teóricos da Gramática Sistêmico-Funcional (HALLIDAY, 2014), tendo destaque para a metafunção ideacional. O corpus apresentou um número total de 44 orações. A partir dos padrões encontrados no Sistema de Transitividade, os dados foram interpretados conforme Fuzer e Cabral (2014). Em um último momento, os dados serviram para interpretar a linguagem como gênero, considerando o contexto de produção, consumo e publicação do texto analisado, seguindo Motta-Roth (2008). Concluiu-se que o exemplar de gênero apresenta características tanto do jornalismo informativo como do jornalismo de opinião, conforme (DIAS, et al., 2006).

Palavras-chave: Gramática Sistêmico-Funcional, Metafunção Ideacional, Representação, Ensino de Língua Portuguesa, Revista Nova Escola.

\section{ANALYSIS OF IDEATIONAL MEANINGS IN NOVA ESCOLA NEWS REPORT: THE REPRESENTATION OF TEACHING AND PORTUGUESE LANGUAGE TEACHERS}

\begin{abstract}
Despite the fact that national guidelines such as PCNs (Parâmetros Curriculares Nacionais) from 1998 and OCNs (Orientações Curriculares Nacionais) from 2006, discuss about Portuguese language teaching in Brazil, manners of improving pedagogical practices are still widely debated in media sphere. This study aimed at analyzing a news report by Maria Rehder published on Nova Escola magazine in January 2010 entitled $O$ que ensinar em Língua Portuguesa do 60 ao 9o ano in order to seek the representation of teaching and Portuguese language teachers portrayed on it. The analysis was carried out under the theoretical principles of Systemic-Functional Grammar (HALLIDAY, 2014), highlighting the ideational metafunction. The corpus presented a total number of 44 clauses. From the patterns found in the Transitivity System, data were interpreted according to Fuzer e Cabral (2014). Ultimately, data served to interpret language as genre, considering the context of production, consumption and publication of the text analyzed, according to Motta-Roth (2008). It was concluded that the exemplar of genre presents features from both informative and opinion journalism, according to (DIAS, et al., 2006).
\end{abstract}


Keywords: Systemic-Functional Grammar, Ideational Metafunction, Representation, Portuguese Language Teaching, Nova Escola Magazine.

\section{INTRODUÇÃO}

O ensino de Língua Portuguesa no Brasil é bastante diversificado, sofrendo variações temporais, regionais e teórico-metodológicas. Buscando uma tentativa de padronização para a existência de um núcleo comum de ensino, o Ministério da Educação (MEC) elaborou e publicou dois documentos basilares para a educação brasileira: os Parâmetros Curriculares Nacionais (PCN), em 1998 e as Orientações Curriculares para o Ensino Médio, em 2006.

Embora normativas nacionais ditem procedimentos de ensino, ainda há muitos aspectos a serem pesquisados no campo do ensino de Língua Portuguesa, dados os grandes avanços em acesso à tecnologia e outras mudanças sociais, como o Novo Acordo Ortográfico da Língua Portuguesa, por exemplo, cuja adesão tornou-se obrigatória a partir de 1 o de janeiro de 2016. Além da esfera governamental, a esfera midiática também apresenta materiais que discutem questões de ensino e aprendizagem. Tais materiais podem servir como fontes de busca aos professores para o aprimoramento e atualização das suas metodologias de ensino. Portanto, há uma necessidade de esses materiais serem estudados a fim de se analisar a forma pela qual o ensino e o professor estão neles representados.

Um grande veículo de difusão de informações sobre a educação no Brasil é a revista Nova Escola. Considerando o público-alvo dessa revista, que se direciona a professores da Educação Básica pública e privada de ensino de todo o país, o estudo desse veículo torna-se relevante uma vez que ele pode ser uma grande fonte de busca de informações para o aperfeiçoamento e a reflexão de profissionais da educação em todo o território nacional. A revista Nova Escola publica reportagens que contemplam diversas disciplinas da grade curricular do ensino brasileiro, dentre as quais se encontra a Língua Portuguesa.

Nesse sentido, o objetivo desse estudo foi analisar uma reportagem de Maria Rehder publicada na revista Nova Escola em janeiro de
2010 intitulada $O$ que ensinar em Língua Portuguesa do 6o ao 9o ano. A análise realizada foi guiada pelos princípios teóricos da Gramática Sistêmico-Funcional (HALLIDAY, 2014), tendo destaque para a metafunção ideacional.

\section{MÉTODOS}

\section{O corpus e procedimentos analíticos}

A fim de analisar a reportagem selecionada à luz da Gramática SistêmicoFuncional, o texto foi parcelado em orações que foram contabilizadas e posteriormente analisadas separadamente. A análise individual das orações buscou identificar os Processos, Participantes e Circunstâncias, seguindo Halliday (2014) e Thompson (2004).

O corpus apresentou um número total de 44 orações. ${ }^{1}$ O maior número de Processos identificados foram Processos Materiais (16), seguidos de Processos Relacionais (13), Processos Verbais (9) e Processos Mentais (6). Não foram mapeados Processos Comportamentais e Existenciais no corpus. Após a contabilização dos tipos de Processos encontrados, foi possível identificar os Participantes neles envolvidos e, posteriormente, as Circunstâncias presentes nas orações. A partir dos padrões encontrados no Sistema de Transitividade, os dados foram interpretados conforme Fuzer e Cabral (2014). Em um último momento, os dados serviram para interpretar a linguagem como gênero, considerando o contexto de produção, consumo e publicação do texto analisado, seguindo MottaRoth (2008).

\section{RESULTADOS}

Como uma maneira de descrever a gramática da "língua humana", a Gramática Sistêmico-Funcional (GSF) considera a gramática

\footnotetext{
${ }^{1}$ Uma vez que o corpus apresentou um número de 44 orações, ele também apresentou 44 Processos, pois Processos equivalem aos verbos na Gramática Tradicional. Dessa forma, assim como na Gramática Tradicional dizemos que onde há oração, há verbo, na Gramática Sistêmico-Funcional, dizemos que onde há oração, há Processo.
} 
como um sistema de escolhas não arbitrariamente motivadas e tenta explicar as implicações comunicativas de uma seleção dentro desse sistema a fim de analisar as motivações que promovem escolhas lexicais particulares (HALLIDAY, 2014). A Gramática Sistêmico-Funcional concebe a língua como tendo três metafunções: ideacional, interpessoal e textual (HALLIDAY, 2014). A metafunção ideacional ou experiencial está relacionada a como os indivíduos experienciam o mundo, a metafunção interpessoal revela como os indivíduos interagem quando eles trocam significados em termos de papéis sociais e relações e a metafunção textual preocupa-se com a organização (arranjo) das orações.

A metafunção ideacional, que é a ferramenta analítica utilizada nesse trabalho, pode ser mapeada através do Sistema de Transitividade (HALLIDAY, 2014). Esse sistema consiste de Participantes, Processos e Circunstâncias. Os Participantes são as pessoas ou coisas representadas na língua e envolvidas ou afetadas por um Processo. Os Processos podem ser de seis tipos: Material, Comportamental, Mental, Verbal, Relacional e Existencial. As Circunstâncias servem para realçar e especificar os Processos em termos de localização, modo, contingência, ângulo, razão e assim por diante.

Sendo o gênero textual em questão pertencente à esfera midiática jornalística, é necessário considerá-lo dentro desse contexto. Dias et al (2006) teorizam sobre os gêneros da comunicação em massa:

Os gêneros da comunicação de massa assumem papel de grande importância no processo de legitimação e autonomia das Ciências da Comunicação. À comunidade científica, os gêneros são fundamentais pois permitem a discussão sobre a abrangência dos fenômenos

Para Dias et al. (2006, p. 4) o jornalismo informativo apresenta os seguintes gêneros textuais: Nota, Notícia, Entrevista e Reportagem, sendo o último o gênero analisado nesse trabalho. Medina (2006) também escreve sobre os gêneros jornalísticos e aponta a reportagem como um gênero informativo. comunicacionais como prática estruturadora e construtora de significados na sociedade. Os gêneros são os lugares da apropriação empírica do investigador onde são apontadas as linhas gerais dos procedimentos analíticos para a compreensão da comunicação, sua natureza e suas dinâmicas internas como campo autônomo de conhecimento. (DIAS, et al.,2006, p. 2)

Dias et al (2006) estabelecem diferenças entre jornalismo informativo, interpretativo e de opinião:

O jornalismo informativo é
aquele que tem
predominantemente por
objeto a informação da
atualidade; seu fim principal é
dar conta do que acontece
(...). O jornalismo

interpretativo é um modo de aprofundar a informação; seu fim principal é o de relacionar a informação da atualidade com seu contexto temporal e espacial; tem, pois, um sentido conjuntural e não se limita a dar conta do que acontece, já que o jornalista interpreta o sentido dos acontecimentos. No jornalismo de opinião, a recompilação de dados informativos é subsidiária, o principal é que o jornalista toma posição a partir desses dados e trata de convencer o leitor de que esta tomada de partido é a mais adequada ou correta". (DIAS et al., 2006, p. 8)

A reportagem analisada apresentou uma clara divisão. Sua primeira parte consiste de 23 orações, que apresentaram Processos Verbais (9), Relacionais (8) e Materiais (6). A segunda parte da reportagem consiste de 21 orações, que apresentaram Processos Materiais (10), Relacionais (5) e Mentais (6). Começaremos discutindo a 
primeira parte da reportagem e os tipos de Processos que nela apareceram separadamente.

\section{Primeira Parte}

A primeira parte da reportagem é uma introdução e contextualização dos problemas existentes na questão de ensino e aprendizagem de Língua Portuguesa. Essa parte traz também algumas definições sobre o que deve ser ensinado e desenvolvido pelos alunos além de algumas opiniões, realizações, constatações e possíveis soluções feitas por especialistas na área.

\section{Processos Verbais}

Todos os Processos Verbais encontrados no corpus ocorreram na primeira parte da reportagem. Fuzer e Cabral $(2014$, p. 72$)$ afirmam que "as orações verbais têm como núcleo os processos do dizer. (...) permitem ao jornalista, em reportagens, atribuir informações a fontes exteriores". Ainda afirmam que "os participantes das orações verbais são tipicamente os seguintes: Dizente, Verbiagem, Receptor e Alvo" (p. 72). Tais Participantes são definidos como: Dizente - o próprio falante, Verbiagem - o que é dito, Receptor - a quem é dirigida a mensagem e Alvo - entidade atingida pelo processo de dizer (FUZER; CABRAL, 2014). Vejamos alguns exemplos de Processos Verbais encontrados no corpus:

\begin{tabular}{|l|l|l|}
\hline Dizente & \multicolumn{1}{|c|}{$\begin{array}{c}\text { Processo } \\
\text { Verbal }\end{array}$} & \multicolumn{1}{|c|}{ Verbiagem } \\
\hline Bazzoni & lembra & $\begin{array}{l}\text { a importância das } \\
\text { atividades sobre } \\
\text { oralidade, destacando a } \\
\text { escuta de textos do } \\
\text { gênero marcados por } \\
\text { maior formalidade, } \\
\text { como seminários, } \\
\text { relatos de experiência, } \\
\text { entrevistas e debates. }\end{array}$ \\
\hline
\end{tabular}

\begin{tabular}{|l|l|l|}
\hline \multicolumn{1}{|c|}{ Alvo } & \multicolumn{1}{|c|}{$\begin{array}{c}\text { Processo } \\
\text { Verbal }\end{array}$} & \multicolumn{1}{|c|}{ Dizente } \\
\hline $\begin{array}{l}\text { Com } \\
\text { ele, }\end{array}$ & Concorda & $\begin{array}{l}\text { Maria José Pinheiro } \\
\text { Machado, da Faculdade } \\
\text { de Educação da } \\
\text { Pontifícia Universidade } \\
\text { Católica de São Paulo } \\
\text { (PUC-SP). }\end{array}$ \\
\hline
\end{tabular}

Ainda sobre as orações verbais, Fuzer e Cabral (2014, p. 74) afirmam que "é comum o papel da verbiagem ser realizado por outra oração. [...] A oração que complementa o processo verbal poderá vir em forma de Citação ou Relato". Citação é definida como "é uma oração projetada que reproduz a fala, introduzida na escrita, geralmente por aspas (...)" (FUZER; CABRAL, 2014, p. 74).

Vejamos alguns exemplos de Citação encontrados no corpus:

\begin{tabular}{|l|l|l|}
\hline \multicolumn{1}{|c|}{ Citação } & $\begin{array}{l}\text { Processo } \\
\text { Verbal }\end{array}$ & \multicolumn{1}{|c|}{ Dizente } \\
\hline $\begin{array}{l}\text { "Os professores são } \\
\text { impelidos a } \\
\text { ministrar aulas de } \\
50 \text { ou 100 minutos } \\
\text { que não mantêm } \\
\text { necessariamente } \\
\text { uma relação entre } \\
\text { os conteúdos", }\end{array}$ & & $\begin{array}{l}\text { Telma Ferraz } \\
\text { Leal, docente } \\
\text { da } \\
\text { Universidade }\end{array}$ \\
\hline
\end{tabular}

\begin{tabular}{|l|l|}
\hline Citação & Processo Verbal \\
\hline "É preciso definir prioridades e & acrescenta. \\
usar o tempo pedagógico para & \\
que as habilidades e os & \\
conhecimentos mais relevantes & \\
para a vivência social dos & \\
estudantes sejam de fato & \\
contemplados", & \\
\hline
\end{tabular}

\begin{tabular}{|l|l|}
\hline Citação & \multicolumn{1}{|c|}{$\begin{array}{c}\text { Processo } \\
\text { Verbal }\end{array}$} \\
\hline $\begin{array}{l}\text { "Tudo começa em sala, com a } \\
\text { apresentação de textos de } \\
\text { autores e gêneros variados. } \\
\text { Depois, os alunos podem } \\
\text { aprofundar a leitura em reuniões } \\
\text { semanais, assumindo a cadeira } \\
\text { de um escritor específico", }\end{array}$ \\
\hline
\end{tabular}

Fuzer e Cabral (2014, p. 75) definem Relato como "uma oração introduzida por conjunção QUE ou SE [...]". Vejamos a seguir o único exemplo de Relato encontrado no corpus: 


\begin{tabular}{|l|l|l|}
\hline \multicolumn{1}{|c|}{ Dizente } & \multicolumn{1}{|c|}{$\begin{array}{l}\text { Processo } \\
\text { Verbal }\end{array}$} & \multicolumn{1}{|c|}{ Relato } \\
\hline Claudio Bazzoni, & Destaca & que a língua é \\
assessor de Língua & & orr ponto \\
Portuguesar da & & essencial do \\
prefeitura de São & & convívio \\
Paulo e & & interpessoal. \\
selecionador do & & \\
Prêmio Victor Civita & & \\
- Educador Nota 10, & & \\
\hline
\end{tabular}

O corpus analisado também apresentou várias Citações, cujos Processos Verbais estavam implícitos e seus Dizentes podiam ser recuperados nas orações antecedentes. Vejamos tais Citações:

\begin{tabular}{|l|l|l|}
\hline Citação & \multicolumn{1}{|c|}{$\begin{array}{c}\text { Processo } \\
\text { Verbal } \\
\text { Implícito }\end{array}$} & \multicolumn{1}{|c|}{$\begin{array}{l}\text { Dizente } \\
\text { recuperado na } \\
\text { oração } \\
\text { antecedente }\end{array}$} \\
\hline $\begin{array}{l}\text { "Tal organização } \\
\text { do tempo escolar } \\
\text { dificultara } \\
\text { realização de } \\
\text { atividades mais } \\
\text { sequenciais". }\end{array}$ & $\begin{array}{l}\text { Telma Ferraz } \\
\text { Leal }\end{array}$ \\
\hline
\end{tabular}

\begin{tabular}{|l|l|l|}
\hline \multicolumn{1}{|c|}{ Citação } & \multicolumn{1}{|c|}{$\begin{array}{c}\text { Processo } \\
\text { Verbal } \\
\text { Implícito }\end{array}$} & $\begin{array}{c}\text { Dizente } \\
\text { recuperado na } \\
\text { oração } \\
\text { antecedente }\end{array}$ \\
\hline "A linguagem é & (disse) & Claudio Bazzoni \\
uso e interação & & \\
entre sujeitos que \\
fazem parte de um \\
determinado \\
contexto histórico \\
e social. É um \\
desafio para o \\
professor assumir \\
que os \\
conhecimentos \\
que os estudantes \\
devem dominar \\
vão além dos \\
contemplados \\
pela gramática \\
normativa".
\end{tabular}

\begin{tabular}{|c|c|c|}
\hline Citação & $\begin{array}{l}\text { Processo } \\
\text { Verbal } \\
\text { Implícito }\end{array}$ & $\begin{array}{l}\text { Dizente } \\
\text { recuperado na } \\
\text { oração } \\
\text { antecedente }\end{array}$ \\
\hline \begin{tabular}{lr}
\multicolumn{2}{l}{ "Isso é necessário } \\
para que eles \\
possam ampliar as \\
condições & de \\
interação e as \\
possibilidades de \\
informação & e \\
conhecimento". &
\end{tabular} & (disse) & $\begin{array}{l}\text { Maria José } \\
\text { Pinheiro } \\
\text { Machado }\end{array}$ \\
\hline
\end{tabular}

A presença das orações verbais no corpus justifica-se pela necessidade de se atribuir ao texto vozes de pessoas qualificadas para opinar sobre questões de ensino e aprendizagem de língua portuguesa. Dessa forma, a autora da reportagem Maria Rehder torna seu texto mais crível do ponto de vista científico, uma vez que as vozes trazidas nas orações verbais são de especialistas no assunto.

\section{Processos Relacionais}

Para Fuzer e Cabral (2014, p. 65.), "as orações relacionais são comumente usadas para representar seres no mundo em termos de suas características e identidades. (...) contribuem na definição de coisas, estruturando conceitos", podendo ser de três tipos: intensivas, possessivas e circunstanciais. As orações intensivas caracterizam uma entidade e geralmente ocorrem com os verbos SER e ESTAR (FUZER; CABRAL, 2014, p. 66). Por sua vez, as orações circunstanciais relacionam duas entidades em termos de tempo, modo, lugar, causa, acompanhamento, papel, assunto ou ângulo (FUZER; CABRAL, 2014, p. 66). Finalmente, as orações possessivas estabelecem uma relação de posse, na qual uma entidade possui a outra (FUZER; CABRAL, 2014, p. 66).

Além de apresentarem três tipos, as orações relacionais podem estar em dois modos: atribuidor e identificador (FUZER; CABRAL, 2014). No modo atribuidor, há um Participante que tem um atributo " $x$ ", já no modo identificador, o Participante tem uma identidade " $x$ ". As orações identificadoras possuem a propriedade da reversibilidade. Por exemplo: "Dilma é a Presidente da República" pode ser dito "A Presidente da 
República é Dilma" (FUZER; CABRAL, 2014, p. 6769).

Na primeira parte da reportagem, foram identificadas orações relacionais intensivas no modo identificador (6), uma oração relacional intensiva no modo atribuidor e uma oração relacional circunstancial no modo atribuidor. A seguir, estão as ocorrências das orações relacionais e seus Participantes no modo identificador.

\begin{tabular}{|l|l|l|}
\hline Identificado & $\begin{array}{c}\text { Processo } \\
\text { Relacional }\end{array}$ & \multicolumn{1}{|c|}{ Identificador } \\
\hline $\begin{array}{l}\text { A meta da é } \\
\text { disciplina }\end{array}$ & $\begin{array}{l}\text { permitir que os } \\
\text { estudantes leiam e } \\
\text { produzam textos de } \\
\text { qualidade, além de } \\
\text { desenvolver a } \\
\text { oralidade }\end{array}$ \\
\hline
\end{tabular}

\begin{tabular}{|l|l|l|}
\hline \multicolumn{1}{|c|}{ Identificador } & $\begin{array}{c}\text { Processo } \\
\text { Relacional }\end{array}$ & Identificado \\
\hline $\begin{array}{l}\text { Esses (formar alunos } \\
\text { capazes de usar } \\
\text { adequadamente a }\end{array}$ & $\begin{array}{l}\text { os objetivos } \\
\text { das aulas de } \\
\text { língua }\end{array}$ \\
$\begin{array}{l}\text { suas materna, em } \\
\text { escrita e oral, e } \\
\text { refletir criticamente } \\
\text { sobre o que leem e } \\
\text { escrevem) }\end{array}$ & & \\
\hline
\end{tabular}

\begin{tabular}{|l|l|l|}
\hline \multicolumn{1}{|c|}{ Identificador } & \multicolumn{1}{|c|}{$\begin{array}{c}\text { Processo } \\
\text { Relacional }\end{array}$} & \multicolumn{1}{|c|}{ Identificado } \\
\hline $\begin{array}{l}\text { Saber argumentar, } \\
\text { fazer São }\end{array}$ & fundamentais \\
entre os texõos & & \\
lidos e ter uma & & \\
atitude crítica & & \\
perante as & & \\
informações & & \\
habilidades & & \\
\hline
\end{tabular}

\begin{tabular}{|l|l|l|}
\hline \multicolumn{1}{|c|}{ Identificado } & \multicolumn{1}{|c|}{$\begin{array}{c}\text { Processo } \\
\text { Relacional }\end{array}$} & \multicolumn{1}{|c|}{ Identificador } \\
\hline $\begin{array}{l}\text { Entretanto, uma } \\
\text { das dificuldades } \\
\text { para atingir tais } \\
\text { objetivos }\end{array}$ & & $\begin{array}{l}\text { os currículos } \\
\text { fragmentados. }\end{array}$ \\
\hline
\end{tabular}

\section{Identificado}

\begin{tabular}{|c|l|l|}
\hline $\begin{array}{l}\text { Outro desafio, de } \\
\text { acordo com } \\
\text { Telma, }\end{array}$ & Relacional & \\
\hline \multicolumn{1}{|c|}{ Identificado } & $\begin{array}{l}\text { Processo } \\
\text { Relacional }\end{array}$ & $\begin{array}{l}\text { romper com o } \\
\text { excesso de } \\
\text { conteúdos }\end{array}$ \\
\hline $\begin{array}{l}\text { Para ela, a } \\
\text { inclusão de um } \\
\text { trabalho com os } \\
\text { gêneros orais nos } \\
\text { currículos }\end{array}$ & representaria & $\begin{array}{l}\text { um avanço, } \\
\text { uma vez que } \\
\text { o tema } \\
\text { costuma fora } \\
\text { ficar de fora } \\
\text { de muitas } \\
\text { práticas } \\
\text { escolares. }\end{array}$ \\
\hline
\end{tabular}

A seguir, estão a oração relacional intensiva no modo atributivo e a oração relacional circunstancial no modo atributivo respectivamente:

\begin{tabular}{|c|c|l|}
\hline \multicolumn{1}{|c|}{ Portador } & \multicolumn{1}{|c|}{$\begin{array}{c}\text { Processo } \\
\text { Relacional }\end{array}$} & \multicolumn{1}{|c|}{ Atributo } \\
\hline $\begin{array}{l}\text { As atividades } \\
\text { de produção }\end{array}$ & devem ser & texto \\
de & & permanentes. \\
\hline
\end{tabular}

\begin{tabular}{|c|c|c|}
\hline $\begin{array}{l}\text { Processo } \\
\text { Relacional }\end{array}$ & Atributo & Portador \\
\hline É & $\begin{array}{l}\text { nesse } \\
\text { contexto }\end{array}$ & $\begin{array}{l}\text { que o momento de } \\
\text { planejamento se } \\
\text { torna fundamental } \\
\text { para que os } \\
\text { professores possam } \\
\text { se dedicar à } \\
\text { discussão sobre } \\
\text { como garantir a } \\
\text { continuidade em } \\
\text { função das } \\
\text { condições de cada } \\
\text { escola. }\end{array}$ \\
\hline
\end{tabular}

A grande presença de orações relacionais identificadoras no corpus justifica-se em função de essa primeira parte da reportagem precisar definir conceitos e pontos de vista sobre a questão de ensino e aprendizagem de língua portuguesa. Para Fuzer e Cabral (2014, p. 69), "esse tipo de oração serve para representar a identidade única de um ser".

Com as orações relacionais identificadoras, são definidas não só as ideias da própria autora Maria Rehder, mas também aquelas 
das pessoas, cujas vozes foram trazidas pelas orações verbais. Logo, faz-se necessário identificar quais são as ideias das pessoas cujas vozes estão presentes na reportagem.

Sobre as orações relacionais atributivas, Fuzer e Cabral (2014, p. 67) afirmam que "[elas] atribuem a uma entidade características comuns aos membros dessa classe". A baixa ocorrência dessas orações no corpus mostra que não há uma preocupação por parte da autora da reportagem em atribuir características comuns, mas sim em evidenciar a identidade das questões sobre ensino e aprendizagem de língua portuguesa, utilizando-se das orações relacionais identificadoras.

\section{Processos Materiais}

Para Fuzer e Cabral (2014, p. 46), orações materiais são "definidas como orações de 'fazer e acontecer', porque estabelecem uma quantidade de mudança no fluxo de eventos". As orações materiais possuem dois participantes principais: o Ator, Participante que inicia o Processo e a Meta, e o Participante, que é resultado do Processo ou afetado por ele (FUZER; CABRAL, 2014).

As orações materiais podem ser de dois tipos: criativas e transformativas. Nas orações materiais criativas, a Meta passa a existir no mundo após a ação realizada pelo Ator, enquanto que nas orações materiais transformativas tanto Ator quanto Meta existem no mundo antes do Processo, porém têm algum aspecto alterado após o Processo.

Das seis orações materiais encontradas na primeira parte da reportagem, três foram classificadas como criativas e as outras três como transformativas. A seguir, estão as orações criativas:

\begin{tabular}{|c|c|c|c|c|}
\hline ncia & $\begin{array}{c}\text { so } \\
\text { Materi } \\
\mathrm{al}^{2}\end{array}$ & & $\begin{array}{c}\text { sso } \\
\text { Mater } \\
\text { ial }\end{array}$ & \\
\hline $\begin{array}{l}\text { Para que } \\
\text { os alunos } \\
\text { dominem } \\
\text { essa } \\
\text { ferramen } \\
\text { ta, }\end{array}$ & cabe & $\begin{array}{l}\text { a todos } \\
\text { os } \\
\text { professo } \\
\text { res }\end{array}$ & $\begin{array}{l}\text { propo } \\
\text { r }\end{array}$ & $\begin{array}{l}\text { situações } \\
\text { didáticas } \\
\text { que } \\
\text { garanta } \\
\text { m, de } \\
\text { maneira } \\
\text { contínua, } \\
\text { a } \\
\text { abordage } \\
\text { m de } \\
\text { gêneros } \\
\text { diversos } \\
\text { - } \\
\text { seleciona } \\
\text { dos em } \\
\text { função } \\
\text { de temas } \\
\text { de } \\
\text { estudo e } \\
\text { com grau } \\
\text { de } \\
\text { dificulda } \\
\text { de } \\
\text { crescent } \\
\text { e. }\end{array}$ \\
\hline
\end{tabular}

\begin{tabular}{|l|l|l|}
\hline $\begin{array}{c}\text { Elemento da } \\
\text { metafunção } \\
\text { textual }\end{array}$ & \multicolumn{1}{|c|}{$\begin{array}{c}\text { Processo } \\
\text { Material }\end{array}$} & \multicolumn{1}{|c|}{ Meta $^{\mathbf{4}}$} \\
\hline Assim, & $\begin{array}{l}\text { seriam } \\
\text { desenvolvidas }\end{array}$ & $\begin{array}{l}\text { as capacidades } \\
\text { comunicativas } \\
\text { dos alunos. }\end{array}$ \\
\hline
\end{tabular}

\begin{tabular}{|l|l|l|l|}
\hline Circunstância & Ator & Processo & Meta \\
\hline
\end{tabular}

\footnotetext{
2 Nessa oração, o processo material está com seus dois vocábulos separados porque a frase não está na ordem direta, a qual seria "A todos os professores cabe propor situações didáticas que garantam, de maneira contínua, a abordagem de gêneros diversos - selecionados em função de temas de estudo e com grau de dificuldade crescente para que os alunos dominem essa ferramenta.

${ }^{3}$ Identificado aqui para esclarecer que não é um Participante do Processo, é um elemento pertencente à metafunção textual, que não é abordada nesse estudo.

${ }^{4}$ Nessa oração, temos uma Meta sem Ator uma vez que esse foi omitido da voz passiva.
} 


\begin{tabular}{|l|l|l|l|}
\hline & & Material & \\
\hline $\begin{array}{l}\text { Inspirada na } \\
\text { Academia } \\
\text { Brasileira de } \\
\text { Letras (ABL), }\end{array}$ & & criou & a Academia \\
& & & $\begin{array}{l}\text { Estudantil de } \\
\text { Letras (AEL) } \\
\text { numa escola } \\
\text { municipal de } \\
\end{array}$ \\
& & São Paulo. \\
\hline
\end{tabular}

A seguir, temos as orações materiais transformativas:

\begin{tabular}{|l|l|l|}
\hline \multicolumn{1}{|c|}{ Ator } & \multicolumn{1}{c|}{$\begin{array}{c}\text { Processo } \\
\text { Mental }\end{array}$} & \multicolumn{1}{c|}{ Meta } \\
\hline $\begin{array}{l}\text { Maior } \\
\text { importância para } \\
\text { o oral }\end{array}$ & equilibra & o currículo. \\
\hline
\end{tabular}

\begin{tabular}{|c|c|c|c|}
\hline Circunstância & Ator & $\begin{array}{l}\text { Processo } \\
\text { Material }\end{array}$ & Meta \\
\hline Desde 2005, & $\begin{array}{l}\text { a } \\
\text { professora } \\
\text { de Língua } \\
\text { Portuguesa } \\
\text { Maria Sueli } \\
\text { Gonçalves }\end{array}$ & abriu & $\begin{array}{l}\text { mais } \\
\text { espaço } \\
\text { para a } \\
\text { oralidade } \\
\text { em seu } \\
\text { trabalho. }\end{array}$ \\
\hline
\end{tabular}

\begin{tabular}{|l|l|l|}
\hline \multicolumn{1}{|c|}{ Meta $^{\mathbf{5}}$} & \multicolumn{1}{|c|}{$\begin{array}{c}\text { Processo } \\
\text { Material }\end{array}$} & \multicolumn{1}{|c|}{ Circunstância } \\
\hline $\begin{array}{l}\text { O gênero } \\
\text { oral }\end{array}$ & é praticado & $\begin{array}{l}\text { nos momentos em que } \\
\text { cada estudante organiza } \\
\text { seminários sobre a } \\
\text { biografia e os textos do } \\
\text { autor representado e } \\
\text { quando recebem } \\
\text { escritores profissionais, } \\
\text { como Tatiana Belinky e } \\
\text { Paulo Dantas. }\end{array}$ \\
\hline
\end{tabular}

A presença das orações materiais na primeira parte da reportagem, sejam elas criativas ou transformativas, justifica-se pela necessidade de se mostrar algumas realizações que foram ou devem ser atingidas para o aprimoramento do ensino e aprendizagem de Língua Portuguesa. Tais realizações são, em sua maioria, oriundas dos sujeitos, cujas vozes foram introduzidas na reportagem pelas orações mais recorrentes - as orações verbais, ou tarefas a cargo dos professores.

\footnotetext{
${ }^{5} \mathrm{O}$ ator que age sobre a Meta não está explícito nessa oração de voz
} passiva, porém se subentende que sejam os alunos
Dessa forma, Maria Rehder mostra que há agentes (especialistas na área), criando e transformando situações relacionadas às questões de ensino e aprendizagem de língua portuguesa. A autora também posiciona a figura do professor como agente transformador ao colocá-lo como Ator nas orações materiais.

\section{Segunda Parte}

A segunda parte da reportagem funciona como um guia esquematizado de ensino, apresentando cinco situações didáticas que Maria Rehder julga essenciais para o ensino de língua portuguesa do 6으 ao 9ㅇ ano. Essa parte apresenta um padrão de distribuição de Processos, uma vez que ela busca ser um esquema prático.

Ela inicia-se com uma oração mental no modo imperativo, o que deixa bem sinalizado a divisão da reportagem. Após, há a especificação de cinco situações didáticas, que estão construídas por meio de uma sequência de orações que se repete cinco vezes (uma vez para cada situação didática) até o final da reportagem $A$ seguir, temos um esclarecimento sobre os Processos Mentais, acompanhado da discussão do padrão de distribuição de orações.

\section{Processos Mentais}

Para Fuzer e Cabral (2014, p. 54), as orações mentais "constituem processos que se referem à experiência do mundo de nossa consciência. [...] Servem, assim, para construir o processo da própria consciência do falante". Envolvidos em Processos Mentais, há basicamente dois Participantes: o Experienciador e o Fenômeno. Experienciadores são predominantemente humanos ou coletivos de humanos, que possuem as capacidades de sentir, pensar, perceber e desejar, enquanto que os Fenômenos são os complementos do processo e referem-se aquilo que é "sentido, pensado, percebido ou desejado" (FUZER; CABRAL, 2014, p. 55).

Os Processos Mentais podem ser de afeição, cognição, percepção ou desejo (FUZER; CABRAL, 2014). No corpus, foram identificadas uma oração mental perceptiva e cinco orações mentais cognitivas.

A seguir, vê-se a oração mental perceptiva encontrada:

\begin{tabular}{|l|l|l|}
\hline Processo & Circunstância & Fenômeno \\
\hline
\end{tabular}




\begin{tabular}{|l|l|l|}
\hline Mental & & \\
\hline Veja, & a seguir, & $\begin{array}{l}\text { cinco situações } \\
\text { didáticas } \\
\text { essenciais para o } \\
\text { ensino de Língua } \\
\end{array}$ \\
& & $\begin{array}{l}\text { Portuguesa do 60 } \\
\text { ao 9o ano. }\end{array}$ \\
\hline
\end{tabular}

Essa é a oração que inicia a segunda parte da reportagem. Ela interpela o leitor através do modo imperativo e o posiciona como Experienciador do Processo, chamando-o à percepção do Fenômeno.

\section{O padrão de orações}

\section{Oração relativa identificadora}

$$
+
$$

2. Oração material criativa com circunstância de tempo

$$
+
$$

\section{Oração mental}

4. Oração material criativa com circunstância de modo.

O padrão de orações é construído a partir da situação didática proposta, composta por um grupo nominal que serve de participante para três das quatro orações que montam a sequência. Para exemplificar, temos a seguir a situação didática 1:

\begin{tabular}{|c|}
\hline Leitura de gêneros de diversas esferas discursivas \\
\hline $\begin{array}{c}\text { Participante Identificado em relação à primeira } \\
\text { oração }\end{array}$ \\
\hline $\begin{array}{c}\text { Participante Meta em relação à segunda e terceira } \\
\text { oração }\end{array}$ \\
\hline
\end{tabular}

1. Oração Relacional Identificadora:

\begin{tabular}{|l|l|l|}
\hline O que & $\begin{array}{l}\text { é e analisar a } \\
\text { maior diversidade } \\
\text { de gêneros possível: } \\
\text { romances, contos, } \\
\text { poemas, crônicas, } \\
\text { peças de teatro, } \\
\text { quadrinhos, artigos } \\
\text { canções, e } \\
\text { opinitivos a } \\
\text { científicos, } \\
\text { resenhas, notícias e }\end{array}$ \\
\hline
\end{tabular}

\begin{tabular}{|c|c|c|}
\hline & & $\begin{array}{l}\text { entrevistas, entre } \\
\text { outros }\end{array}$ \\
\hline $\begin{array}{c}\text { Identificado } \\
\text { secundário } \\
\text { (retoma o }\end{array}$ & $\begin{array}{c}\text { Processo } \\
\text { Relacional }\end{array}$ & \\
título da & & \\
situação & & \\
didática) & & \\
\hline
\end{tabular}

2. Oração Material Criativa com Circunstância de Tempo

\begin{tabular}{|c|l|l|}
\hline Quando & propor $^{6}$ & $\begin{array}{l}\text { com a maior } \\
\text { frequência possível, } \\
\text { ao longo de todo o } \\
\text { ano. }\end{array}$ \\
\hline $\begin{array}{c}\text { Circunstância } \\
\text { de Tempo }\end{array}$ & $\begin{array}{c}\text { Processo } \\
\text { Material }\end{array}$ & $\begin{array}{c}\text { Circunstância de } \\
\text { Tempo }\end{array}$ \\
\hline
\end{tabular}

\begin{tabular}{|c|c|c|c|}
\hline $\mathrm{O}$ que & 0 aluno & $\begin{array}{l}\text { Aprend } \\
\mathrm{e}\end{array}$ & $\begin{array}{l}\text { a interagir } \\
\text { com os textos } \\
\text { que circulam } \\
\text { no mundo, } \\
\text { criar uma } \\
\text { expectativa } \\
\text { em função } \\
\text { daquilo que } \\
\text { vai ler e } \\
\text { desenvolver } \\
\text { diferentes } \\
\text { comportamen } \\
\text { tos leitores } \\
\text { diante de } \\
\text { diferentes } \\
\text { gêneros } \\
\text { textuais. }\end{array}$ \\
\hline $\begin{array}{c}\text { Fenôme } \\
\text { no }\end{array}$ & $\begin{array}{c}\text { Experienciad } \\
\text { or }\end{array}$ & $\begin{array}{c}\text { Process } \\
o \\
\text { Mental }\end{array}$ & Fenômeno \\
\hline
\end{tabular}

3. Oração Mental

4. Oração Material Criativa com Circunstância de Modo

\footnotetext{
${ }^{6}$ A Meta desse Processo Material é a situação didática que aparece anteriormente. $\mathrm{O}$ professor é o Ator implícito desse Processo Material.
} 


\begin{tabular}{|c|c|c|}
\hline Como & propor 7 & $\begin{array}{lr}\text { servindo de modelo } \\
\text { como leitor e } \\
\text { orientando } \\
\text { jovens a rastrear } \\
\text { pistas linguísticas } \\
\text { para relacioná-las } \\
\text { com ideias } \\
\text { informações que já } \\
\text { possuem e a } \\
\text { perceber que cada } \\
\text { objetivo de leitura } \\
\text { solicita r um } \\
\text { procedimento. }\end{array}$ \\
\hline $\begin{array}{c}\text { Circunstância } \\
\text { de Modo }\end{array}$ & $\begin{array}{l}\text { Processo } \\
\text { Material }\end{array}$ & $\begin{array}{c}\text { Circunstância de } \\
\text { Modo }\end{array}$ \\
\hline
\end{tabular}

A seguir, está a situação didática 2:

\begin{tabular}{|c|}
\hline $\begin{array}{c}\text { Leitura em profundidade e procedimentos de } \\
\text { estudo }\end{array}$ \\
\hline Participante Identificado em relação à primeira \\
oração \\
\hline $\begin{array}{c}\text { Participante Meta em relação à segunda e terceira } \\
\text { oração }\end{array}$ \\
\hline
\end{tabular}

1. Oração Relacional Identificadora:

\begin{tabular}{|c|c|l|}
\hline O que & É & $\begin{array}{l}\text { ler textos para } \\
\text { estudar e para } \\
\text { interagir com ideias } \\
\text { de outras pessoas e } \\
\text { se apropriar delas } \\
\text { para elaborar seu } \\
\text { próprio discurso. }\end{array}$ \\
\hline $\begin{array}{c}\text { Identificado } \\
\text { secundário } \\
\text { (retomao } \\
\text { título da } \\
\text { situação } \\
\text { didática) }\end{array}$ & Processo & Identificador \\
\hline
\end{tabular}

2. Oração Material Criativa com Circunstância de Tempo

\begin{tabular}{|l|l|l|}
\hline Quando & propor $^{8}$ & nas situações de \\
\hline
\end{tabular}

\footnotetext{
${ }^{7}$ Idem nota de rodapé no 6
}

\begin{tabular}{|c|c|c|}
\hline & & $\begin{array}{lr}\text { pesquisa e nos } \\
\text { momentos de } \\
\text { aprendizagem de } \\
\text { um conteúdo } \\
\text { específico. }\end{array}$ \\
\hline $\begin{array}{c}\text { Circunstância } \\
\text { de Tempo }\end{array}$ & $\begin{array}{l}\text { Processo } \\
\text { Material }\end{array}$ & $\begin{array}{c}\text { Circunstância de } \\
\text { Tempo }\end{array}$ \\
\hline
\end{tabular}

3. Oração Mental

\begin{tabular}{|c|c|c|c|}
\hline $\mathrm{O}$ que & o aluno & $\begin{array}{l}\text { Aprend } \\
\mathrm{e}\end{array}$ & $\begin{array}{l}\text { a fazer } \\
\text { resumos e } \\
\text { fichamento } \\
\text { s, identificar } \\
\text { o tema dos } \\
\text { textos, } \\
\text { diferenciar } \\
\text { as ideias } \\
\text { principais } \\
\text { das } \\
\text { secundárias } \\
\text { e } \\
\text { estabelecer } \\
\text { relações } \\
\text { entre } \\
\text { argumentos } \\
\text { trazidos } \\
\text { pelo autor, } \\
\text { indo além } \\
\text { do } \\
\text { conteúdo } \\
\text { estudado. }\end{array}$ \\
\hline $\begin{array}{c}\text { Fenômen } \\
o\end{array}$ & $\begin{array}{c}\text { Experienciado } \\
r\end{array}$ & $\begin{array}{c}\text { Process } \\
o \\
\text { Mental }\end{array}$ & Fenômeno \\
\hline
\end{tabular}

4. Oração Material Criativa com Circunstância de Modo

\begin{tabular}{l|l|l|}
\hline Como & propor $^{9}$ & discutindo com a \\
\hline \\
\hline${ }^{8}$ A Meta desse Processo Material é a situação didática que aparece \\
anteriormente. O professor é o Ator implícito desse Processo Material. \\
${ }^{9}$ Idem nota de rodapé no 9
\end{tabular}




\begin{tabular}{|c|c|c|}
\hline & & $\begin{array}{l}\text { turma critérios para } \\
\text { descartar pontos } \\
\text { não essenciais do } \\
\text { texto analisado, } \\
\text { explicando como é } \\
\text { a estrutura de um } \\
\text { texto e mostrando } \\
\text { possibilidades de } \\
\text { dividi-lo em grupos } \\
\text { de blocos } \\
\text { significativos. }\end{array}$ \\
\hline $\begin{array}{c}\text { Circunstância } \\
\text { de Modo }\end{array}$ & $\begin{array}{l}\text { Processo } \\
\text { Material }\end{array}$ & $\begin{array}{c}\text { Circunstância de } \\
\text { Modo }\end{array}$ \\
\hline
\end{tabular}

Situação didática 3:

\begin{tabular}{|c|}
\hline Reflexão sobre os padrões de escrita \\
\hline $\begin{array}{c}\text { Participante Identificado em relação à primeira } \\
\text { oração }\end{array}$ \\
\hline $\begin{array}{c}\text { Participante Meta em relação à segunda e terceira } \\
\text { oração }\end{array}$ \\
\hline
\end{tabular}

1. Oração Relacional Identificadora:

\begin{tabular}{|c|c|c|}
\hline O que & É & $\begin{array}{l}\text { planejar situações } \\
\text { didáticas } \\
\text { promovam que } \\
\text { ensino reflexivo a } \\
\text { respeito } \\
\text { conteúdos como } \\
\text { ortografia, } \\
\text { concordância, } \\
\text { regência verbal, } \\
\text { segmentação do } \\
\text { texto em palavras e } \\
\text { frases, pontuação, } \\
\text { entre outros, } \\
\text { ajustados } \\
\text { necessidades de } \\
\text { aprendizagem dos } \\
\text { alunos. }\end{array}$ \\
\hline $\begin{array}{c}\text { Identificado } \\
\text { secundário } \\
\text { (retoma o } \\
\text { título da } \\
\text { situação } \\
\text { didática) }\end{array}$ & $\begin{array}{l}\text { Processo } \\
\text { Relacional }\end{array}$ & Identificador \\
\hline
\end{tabular}

2. $\quad$ Oração Material Criativa com Circunstância de Tempo

\begin{tabular}{|c|c|l|}
\hline Quando & propor $^{10}$ & $\begin{array}{l}\text { em sequências } \\
\text { didáticas } \\
\text { específicas e nas } \\
\text { práticas de escrita } \\
\text { incluídas nos } \\
\text { projetos didáticos. }\end{array}$ \\
\hline $\begin{array}{c}\text { Circunstância de } \\
\text { Tempo }\end{array}$ & $\begin{array}{l}\text { Processo } \\
\text { Material }\end{array}$ & $\begin{array}{c}\text { Circunstância de } \\
\text { Tempo }\end{array}$ \\
\hline
\end{tabular}

3. Oração Mental

\begin{tabular}{|c|c|c|l|}
\hline O que & o aluno & $\begin{array}{l}\text { Aprend } \\
\text { e }\end{array}$ & $\begin{array}{l}\text { as } \\
\text { regularidades } \\
\text { e } \\
\text { irregularidad } \\
\text { es } \\
\text { ortográficas, } \\
\text { pontuar, } \\
\text { identificar } \\
\text { marcas de } \\
\text { coesão } \\
\text { referencial e } \\
\text { sequencial e } \\
\text { transitar da } \\
\text { fala à escrita. }\end{array}$ \\
\hline Fenômen & $\begin{aligned} \text { Experienciad } \\
\text { or }\end{aligned}$ & Process & Fenômeno \\
& & Mental & \\
\hline
\end{tabular}

4. Oração Material Criativa com Circunstância de Modo

\begin{tabular}{l|l|l|}
\hline Como & propor $^{11}$ & por meio de \\
\hline
\end{tabular}




\begin{tabular}{|c|c|c|}
\hline & & $\begin{array}{l}\text { sequências didáticas } \\
\text { com base em uma } \\
\text { sondagem feita } \\
\text { especialmente para } \\
\text { verificar o domínio } \\
\text { dos padrões de } \\
\text { escrita pelos alunos, } \\
\text { de atividades que } \\
\text { explorem as } \\
\text { regularidades } \\
\text { ortográficas e da } \\
\text { leitura de textos } \\
\text { especialmente } \\
\text { selecionados para } \\
\text { trabalhar tempos } \\
\text { verbais, pontuação, } \\
\text { concordância e } \\
\text { regência, entre } \\
\text { outros aspectos. }\end{array}$ \\
\hline $\begin{array}{l}\text { Circunstância } \\
\text { de Modo }\end{array}$ & $\begin{array}{l}\text { Processo } \\
\text { Material }\end{array}$ & $\begin{array}{c}\text { Circunstância de } \\
\text { Modo }\end{array}$ \\
\hline
\end{tabular}

Situação didática 4:

\begin{tabular}{|c|}
\hline Uso de diversos gêneros orais \\
\hline $\begin{array}{c}\text { Participante Identificado em relação à primeira } \\
\text { oração }\end{array}$ \\
\hline $\begin{array}{c}\text { Participante Meta em relação à segunda e terceira } \\
\text { oração }\end{array}$ \\
\hline
\end{tabular}

1. Oração Relacional Identificadora:

\footnotetext{
${ }^{11}$ Idem nota de rodapé no 10
}

dominar os gêneros mais formais que apoiam

a
aprendizagem da Língua Portuguesa e das outras áreas, como seminários, relatos de experiências, entrevistas, debates e palestras.

\begin{tabular}{|c|c|c|}
\hline Identificado & Processo & Identificador \\
secundário & Relacional & \\
(retoma o & & \\
título da & & \\
situação & & \\
didática) & & \\
\hline
\end{tabular}

2. Oração Material Criativa com Circunstância de Tempo

\begin{tabular}{|c|l|c|}
\hline Quando & propor $^{12}$ & $\begin{array}{c}\text { durante sequências } \\
\text { didáticas planejadas } \\
\text { com esse objetivo. }\end{array}$ \\
\hline $\begin{array}{c}\text { Circunstância } \\
\text { de Tempo }\end{array}$ & $\begin{array}{c}\text { Processo } \\
\text { Material }\end{array}$ & $\begin{array}{c}\text { Circunstância de } \\
\text { Tempo }\end{array}$ \\
\hline
\end{tabular}

3. Oração Mental

\begin{tabular}{|c|c|l|l|}
\hline O que & o aluno & $\begin{array}{l}\text { aprend } \\
\text { e }\end{array}$ & $\begin{array}{l}\text { a construir } \\
\text { progressivame } \\
\text { nte modelos } \\
\text { apropriados do } \\
\text { uso da } \\
\text { linguagem oral } \\
\text { em diferentes } \\
\text { circunstâncias } \\
\text { e a participar } \\
\text { de debates, } \\
\text { entrevistas, } \\
\text { palestras e } \\
\text { saraus } \\
\text { organizados } \\
\text { pela escola ou } \\
\text { outras } \\
\text { instituições. }\end{array}$ \\
& & & \\
Fenôme & Experiencia & Process & Fenômeno \\
no & dor & Mental & \\
\hline
\end{tabular}
${ }^{12}$ A Meta desse Processo Material é a situação didática que aparece
anteriormente. O professor é o Ator implícito desse Processo Material. 
4. Oração Material Criativa com Circunstância de Modo

\begin{tabular}{|c|c|c|}
\hline Como & propor $^{13}$ & $\begin{array}{l}\text { por meio do acesso } \\
\text { (em DVDs e vídeos) } \\
\text { a exemplos de } \\
\text { textos orais dos } \\
\text { gêneros previstos } \\
\text { para análise e } \\
\text { reflexão e da } \\
\text { participação em } \\
\text { debates regrados, } \\
\text { apresentações de } \\
\text { painéis } \\
\text { seminários. }\end{array}$ \\
\hline $\begin{array}{c}\text { Circunstância } \\
\text { de Modo }\end{array}$ & $\begin{array}{l}\text { Processo } \\
\text { Material }\end{array}$ & $\begin{array}{c}\text { Circunstância de } \\
\text { Modo }\end{array}$ \\
\hline
\end{tabular}

Situação didática 5:

\begin{tabular}{|c|}
\hline Produção, revisão e edição de textos \\
\hline $\begin{array}{c}\text { Participante Identificado em relação à primeira } \\
\text { oração }\end{array}$ \\
\hline $\begin{array}{c}\text { Participante Meta em relação à segunda e terceira } \\
\text { oração }\end{array}$ \\
\hline
\end{tabular}

1. Oração Relacional Identificadora:

\begin{tabular}{|c|c|l|}
\hline O que & é & $\begin{array}{l}\text { procedimentos que } \\
\text { permitem ao aluno } \\
\text { escrever textos de } \\
\text { gêneros diversos } \\
\text { com intenção } \\
\text { comunicativa. }\end{array}$ \\
\hline $\begin{array}{c}\text { Identificado } \\
\text { secundário } \\
\text { (retoma o } \\
\text { título da } \\
\text { situação } \\
\text { didática) }\end{array}$ & Processo & \multicolumn{1}{|c|}{ Identificador } \\
\hline
\end{tabular}

2. Oração Material Criativa com Circunstância de Tempo

\begin{tabular}{|l|l|l|}
\hline Quando & propor $^{14}$ & $\begin{array}{l}\text { durante projetos } \\
\text { didáticos semestrais } \\
\text { e outras situações } \\
\text { de produção } \\
\text { textual. }\end{array}$ \\
\hline Circunstância & Processo & \multicolumn{2}{|c|}{ Circunstância de } \\
\hline
\end{tabular}

${ }^{13}$ Idem nota de rodapé no 12

${ }^{14}$ A Meta desse Processo Material é a situação didática que aparece anteriormente. O professor é o Ator implícito desse Processo Material.

\begin{tabular}{|l|l|l|}
\hline de Tempo & Material & Tempo \\
\hline
\end{tabular}

3. Oração Mental

\begin{tabular}{|c|c|c|c|}
\hline O que & $\mathrm{o}$ aluno & $\begin{array}{l}\text { aprend } \\
\mathrm{e}\end{array}$ & $\begin{array}{l}\text { a cortar } \\
\text { passagens } \\
\text { redundante } \\
\text { s e marcas } \\
\text { da língua } \\
\text { falada, a } \\
\text { acrescentar } \\
\text { informaçõe } \\
\text { s ou falas } \\
\text { de p } \\
\text { personagen } \\
\text { s para } \\
\text { diminuir as } \\
\text { lacunas do } \\
\text { texto, } \\
\text { substituir } \\
\text { termos por } \\
\text { outros mais } \\
\text { precisos, a } \\
\text { inverter } \\
\text { frases ou } \\
\text { parágrafos } \\
\text { para buscar } \\
\text { melhor } \\
\text { ordem para } \\
\text { as ideias e a } \\
\text { revisar e } \\
\text { diagramar o } \\
\text { próprio } \\
\text { texto. }\end{array}$ \\
\hline $\begin{array}{c}\text { Fenômen } \\
o\end{array}$ & $\begin{array}{c}\text { Experienciado } \\
r\end{array}$ & $\begin{array}{c}\text { Process } \\
o \\
\text { Mental }\end{array}$ & Fenômeno \\
\hline
\end{tabular}


4. Oração Material Criativa com Circunstância de Modo

\begin{tabular}{|c|l|l|}
\hline Como & propor $^{15}$ & $\begin{array}{l}\text { com atividades de } \\
\text { edição que exija } \\
\text { cortar, acrescentar e } \\
\text { inverter trechos ou } \\
\text { passar textos como } \\
\text { depoimentos } \\
\text { espontâneos r e } \\
\text { entrevistas da } \\
\text { linguagem oral para } \\
\text { a escrita. }\end{array}$ \\
\hline $\begin{array}{c}\text { Circunstância } \\
\text { de Modo }\end{array}$ & $\begin{array}{l}\text { Processo } \\
\text { Material }\end{array}$ & \multicolumn{2}{|c|}{ Modo } \\
\hline
\end{tabular}

A presença de orações relacionais identificadoras na segunda parte da reportagem marca a intensão de definir claramente a situação didática proposta por Maria Rehder. Por isso, as situações didáticas encontram-se na posição de Identificados e suas definições como Identificadores.

As orações materiais criativas colocam a responsabilidade de tornar tais propostas pedagógicas existentes sobre o professor, que é posicionado como Ator, cujas Metas são as próprias situações didáticas. Contudo, a palavra "professor" não está escrita nas orações, por isso a chamamos de Ator implícito. Essa conclusão baseou-se na resposta da pergunta "Se espera que quem proponha aquelas situações didáticas?". Certamente, espera-se que seja o professor. As Circunstâncias têm um papel importante nessas orações, uma vez que elas especificam e particularizam a realização dos Processos em termos de tempo e modo.

As orações mentais de cognição posicionam a figura do aluno como Experienciador e definem os Fenômenos que ele deve vivenciar. Portanto, o aluno é posto como um ser que percebe, não como um ser que age, como o professor.

\section{DISCUSSÃO}

A partir dos dados discutidos, podemos afirmar que a reportagem de Maria Rehder tem um público-alvo bastante definido: os professores. A reportagem tem a necessidade de convencer os

\footnotetext{
${ }^{15}$ Idem nota de rodapé no 14
}

professores a proporem algumas situações didáticas para o aprimoramento do ensino e aprendizagem de língua portuguesa. A fim de interpelar esse público de uma maneira suave, a autora usa de estratégias lexicogramaticais para que a reportagem não se torne apenas uma lista de afazeres pedagógicos.

Para tanto, a reportagem inicia com uma introdução que traz vozes de especialistas para torná-la mais consistente. Dessa forma, Maria Rehder expressa que não é apenas ela que pensa que mudanças no ensino devem ser feitas, logo os argumentos de suas propostas se tornam mais fortes.

Na segunda parte da reportagem, temos a voz da própria Maria Rehder, que lista caminhos práticos a serem seguidos pelos professores de língua portuguesa. Em outras palavras, Maria Rehder dá ordens sobre como ensinar. Entretanto, essas ordens são apresentadas de uma maneira um pouco disfarçada e não direta (Seria uma maneira direta se a autora colocasse as orações em modo imperativo, por exemplo ${ }^{16}$ ). Por isso, há orações que simulam uma estrutura de perguntas e respostas, como se o leitor estivesse indagando e obtendo as respostas da autora. Para deixar a reportagem com uma atmosfera ainda mais suave, a figura do professor como Ator não está escrita, porém é implícita.

Dessa forma, podemos afirmar que, por mais que a reportagem seja enquadrada como um gênero jornalístico-informativo (DIAS et. al., 2006), exemplar do gênero traz um pouco do jornalismo de opinião, no qual "o jornalista toma posição a partir desses dados e trata de convencer o leitor de que esta tomada de partido é a mais adequada ou correta". (DIAS, et al., 2006, p. 8).

Considerando o contexto da revista Nova Escola, a reportagem é um gênero feito para e consumido por professores. Esse público-alvo espera que a revista seja uma fonte de busca para estudo e discussão. Por isso, a reportagem de Maria Rehder apresenta situações didáticas esperando que os professores brasileiros a acessem e proporcionem as contribuições que ela traz a seus alunos. Conclui-se que o ensino está representado como estando nas mãos do Ator professor.

\footnotetext{
${ }^{16}$ Conforme o conceito de modo oracional, atos de fala e congruência conforme Halliday (2014).
} 
Essa pesquisa contribui para que professores tenham um maior esclarecimento quando pesquisarem fontes para refletir sobre suas estratégias de ensino. Estudos mais aprofundados e com um corpus maior são necessários para buscar um entendimento melhor no que tange a representações de ensino e do professor na esfera midiática brasileira.

\section{REFERÊNCIAS}

BRASIL. Ministério da Educação. Parâmetros Curriculares Nacionais: ensino médio. 2000. Disponível em: <http://portal.mec.gov.br/seb/arquivos/pdf/14_24 .pdf> Acesso em: 1 nov. 2015.

Ministério da Educação. Secretaria de Educação Básica. Orientações curriculares para o ensino médio: linguagens, códigos e suas tecnologias. Brasília, 2006. Disponível em: < http://portal.mec.gov.br/seb/arquivos/pdf/book_v olume_01_internet.pdf>. Acesso em: 1 nov. 2015.

DIAS, P. et al. Gêneros e formatos na comunicação massiva periodística: um estudo do jornal Folha de S. Paulo e da revista Veja. In: CONGRESSO BRASILEIRO DE CIÊNCIA DA COMUNICAÇÃO, 23., Recife. Anais... São Paulo: Intercom, 1998. Disponível em: <www.intercom.org.br>. Acesso em: 1 nov. 2015.

FUZER, C.; CABRAL, S. Introdução à gramática sistêmico-funcional em língua portuguesa. 1. ed. Campinas: Mercado das Letras, 2014.

HALLIDAY, M. A. K. An introduction to functional grammar. 4. ed. Abingdon: Routledge, 2014.

MEDINA, J. L. B. Gêneros jornalísticos: uma questão de gênero. In: SIMPÓSIO DE COMUNICAÇÃO DA REGIÃO SUDESTE, 7., Vitória. Anais... São Paulo: Intercom, 2001. Disponível em: $<$ www.intercom.org.br/papers/viii-sipec/gt05/40\%20Jorge\%20Lellis\%20-

\%20trabalho\%20completo.htm>. Acesso em: 10 de nov. 2015.

MOTTA-ROTH, D. Análise crítica de gêneros: contribuições para o ensino e a pesquisa de linguagem. D.E.L.T.A., v. 24, n.2, p. 341-383, 2008.
REHDER, M. O que ensinar em Língua Portuguesa do 60 ao 9o ano. Revista Nova Escola. Disponível em <http://revistaescola.abril.com.br/linguaportuguesa/fundamentos/objetivos-aulas-linguaportuguesa-para-6-9-ano-leitura-producao-textooralidade -542869 . shtml?page $=0>$ Acesso em: 1은 de out. 2015.

THOMPSON, G. Introducing functional grammar. 2. ed. Great Britain: [s.n.], 2004.

Recebido para publicação em: 26/04/2016

Revisado em: 29/04/2016

Aceito em: 02/05/2016 